\title{
Transcatheter valve-in-valve implantation for degenerated surgical bioprostheses
}

\author{
Dale J. Murdoch, John G. Webb \\ Centre for Heart Valve Innovation, St. Paul's Hospital, Vancouver, Canada \\ Contributions: (I) Conception and design: All authors; (II) Administrative support: All authors; (III) Provision of study materials or patients: All \\ authors; (IV) Collection and assembly of data: All authors; (V) Data analysis and interpretation: All authors; (VI) Manuscript writing: All authors; (VII) \\ Final approval of manuscript: All authors. \\ Correspondence to: John G. Webb, MD. Centre for Heart Valve Innovation, St. Paul's Hospital, 1081 Burrard Street, Vancouver, BC, Canada. \\ Email: Webb@providencehealth.bc.ca.
}

\begin{abstract}
Transcatheter valve-in-valve (VIV) procedures are less invasive than re-do open heart surgery, and have proven relatively safe and effective. In large multicentre registries morbidity and mortality risks are generally lower than with surgery, and improvement in quality of life can be profound. Outcomes continue to improve with advances in transcatheter heart valve (THV) technology, techniques, and expertise. However specific concerns remain; including residual stenosis, coronary obstruction, left ventricular outflow tract obstruction, and thrombosis. The unknown durability is a concern in patients with the potential for longevity. Transcatheter VIV procedures will likely increasingly be favoured over reoperation when bioprosthetic heart valves fail, particularly when surgical risks are high.
\end{abstract}

Keywords: Valve-in-valve (VIV); transcatheter aortic valve replacement (TAVR); aortic valve; aortic valve replacement

Submitted Apr 07, 2018. Accepted for publication May 03, 2018.

doi: $10.21037 /$ jtd.2018.05.66

View this article at: http://dx.doi.org/10.21037/jtd.2018.05.66

\section{Introduction}

Over 275,000 surgical heart valves are implanted worldwide each year. Bioprosthetic valves are increasingly preferred over mechanical valves, due to the lower risk of thrombo-embolic complications $(1,2)$. However, with time, animal or human tissue leaflets may weaken and calcify, leading to stenosis, regurgitation, or both. Reoperation for bioprosthetic valve failure is associated with significant risks, particularly in patients with comorbidities, including advanced age. Over the past decade less invasive transcatheter valve-in-valve (VIV) procedures have been increasingly utilised in the aortic, mitral, pulmonary and tricuspid positions.

\section{Aortic VIV procedure}

Aortic VIV procedures were first performed in $2007(3,4)$. Access is most often percutaneous from the femoral artery, although surgical access from the left ventricular apex or other large arteries are alternatives. The most commonly used transcatheter heart valves (THVs) are the Sapientype balloon-expandable or the CoreValve self-expandable devices (Figure 1). There is considerable variation in the construction of surgical valves, and detailed knowledge is required to ensure safe and effective THV implantation. Most surgical valves consist of a metal or plastic frame and sewing ring to which are sewn 3 leaflets constructed of bovine or porcine pericardial or leaflet tissue.

Surgical valves are generally labelled by the manufacturer according to their outer diameter. However it is the inner dimensions that are vital for selection of an appropriately sized THV (5). A VIV smartphone application is widely used and references a large range of commonly used surgical and transcatheter valves with descriptions, images, dimensions, photographic and fluoroscopic images, along with guidance on sizing and positioning (6). 

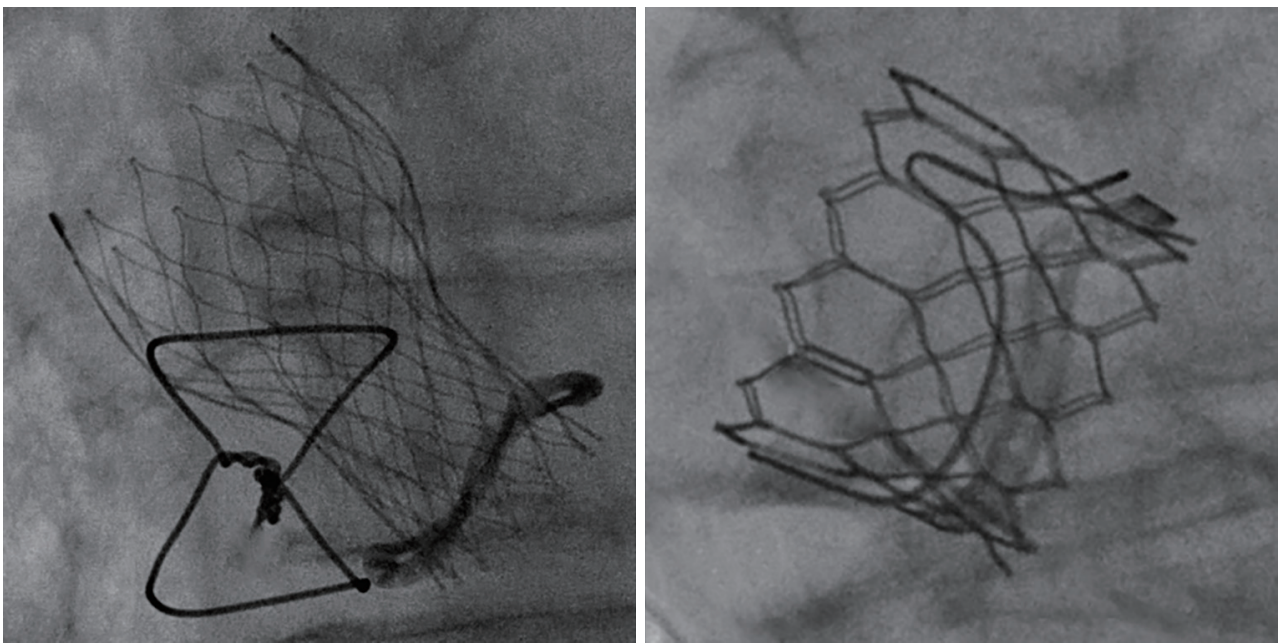

Figure 1 Medtronic CoreValve Evolut R (left) and Edwards SAPIEN 3 (right) THVs deployed within bioprosthetic aortic valves. THVs, transcatheter heart valves.

Table 1 Summary of contemporary valve-in-valve baseline variables and selected outcomes

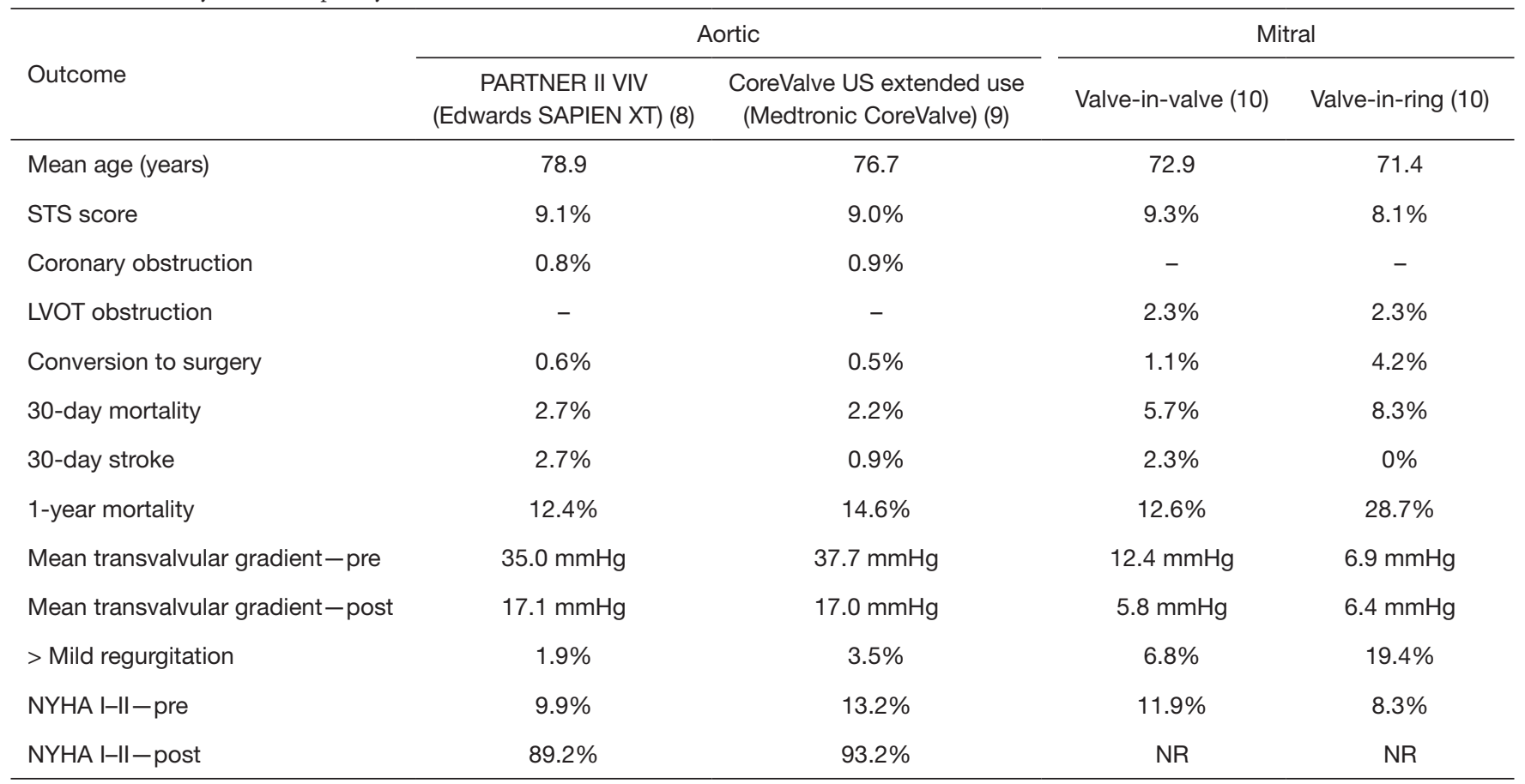

LVOT, left-ventricular outflow tract; NR, not reported.

\section{Aortic VIV outcomes}

Multiple registries have documented improving outcomes with aortic VIV procedures (7). Recent prospective aortic VIV registries demonstrated excellent 30-day and 1-year survival in nearly 600 patients with both balloon-expandable and self-expanding THVs (Table 1) $(8,9)$. Improvements in functional status and quality of life measures were dramatic, and sustained at 1-year. Residual aortic regurgitation, embolization and coronary obstruction were rare.

Higher than desirable residual transvalvular gradients 


\begin{tabular}{|c|c|c|c|}
\hline $\begin{array}{l}\text { Surgical valve } \\
\text { features }\end{array}$ & $\begin{array}{c}\text { SAPIEN } 3 \text { valve positioning } \\
\text { considerations }\end{array}$ & $\begin{array}{l}\text { Surgical valve } \\
\text { features }\end{array}$ & $\begin{array}{c}\text { SAPIEN } 3 \text { valve position } \\
\text { considerations }\end{array}$ \\
\hline Visible stent frame & $\begin{array}{l}\text { Align the base of the central } \\
\text { marker } 3-5 \mathrm{~mm} \text { above the } \\
\text { base of the surgical valve } \\
\text { stent frame }\end{array}$ & Visible stent frame & $\begin{array}{l}\text { Align the base of the central } \\
\text { marker } 3-5 \mathrm{~mm} \text { below the base } \\
\text { (towards ventricle) of the surgic } \\
\text { valve stent frame }\end{array}$ \\
\hline $\begin{array}{l}\text { Visible outflow } \\
\text { markers only } \\
\end{array}$ & $\begin{array}{l}\text { Align the outflow of the } \\
\text { crimaped SAPIEN } 3 \text { valve } \\
2 \text { mm above the surgical } \\
\text { valve outflow markers }\end{array}$ & $\begin{array}{l}\text { Visible outflow } \\
\text { markers only } \\
\text { - }\end{array}$ & $\begin{array}{l}\text { Align the outflow of the crimped } \\
\text { SAPIEN } 3 \text { valve } 2 \mathrm{~mm} \text { below } \\
\text { (towards ventricle) the surgical } \\
\text { valve outflow markers }\end{array}$ \\
\hline $\begin{array}{l}\text { No visible radiopaque } \\
\text { markers }\end{array}$ & $\begin{array}{l}\text { Align the base of the } \\
\text { central marker with the } \\
\text { annular plane }\end{array}$ & $\begin{array}{l}\text { No visible radiopaque } \\
\text { markers }\end{array}$ & $\begin{array}{l}\text { Align the base of the } \\
\text { central marker with the } \\
\text { annular plane }\end{array}$ \\
\hline
\end{tabular}

Figure 2 Recommended positioning of the SAPIEN 3 valve in the aortic position (left) and mitral position (right).

are common after VIV procedures due to incomplete THV expansion. In VIVID registry data, around one-quarter of patients had severe patient-prosthesis mismatch (indexed effective orifice area $<0.65 \mathrm{~cm}^{2} / \mathrm{m}^{2}$ ), although this did not seem to be associated with adverse clinical outcomes in the short term (11). Improved hemodynamic performance in VIV procedures may be attained by implanting the THV 'higher', with leaflets above the neo-annulus as seen in Figure 2 (12). THVs with leaflets placed higher in the frame (e.g., CoreValve Evolut) may allow for "supra-annular" positioning with the potential for lower transvalvular gradients.

Recently, it has been shown that high-pressure balloon dilation has the potential to expand or fracture many surgical valves, allowing more complete THV expansion and reducing post-procedural gradients. Most bioprosthetic surgical valves yield at 8-26 ATM (notable exceptions are Hancock II and Trifecta valves) and clinical complications have been infrequent in several case series $(7,13)$.

\section{Mitral VIV procedure and outcomes}

Mitral VIV procedures were originally performed using a transapical approach requiring a small thoracotomy. More recently percutaneous transseptal access from the femoral vein has gained favour. Mitral bioprostheses are typically large and circular; well suited to implantation of balloonexpandable Sapien-type THVs with little or no paravalvular regurgitation and low transvalvular gradients. Clinical benefit can be profound $(10,14)$.

Mitral annuloplasty rings and bands, however, may be eccentrically shaped and either flexible, semi-rigid or rigid. Although valve-in-ring (VIR) procedures can be effective; risks of embolization, regurgitation, and other complications remain relatively high. Currently VIR procedures should be considered investigational (10).

Left-ventricular outflow tract (LVOT) obstruction is a rare but potentially serious complication of mitral VIV procedures. CT modelling is increasingly performed preprocedure to assess this risk; a THV is virtually implanted and the future 'neo-LVOT' can be assessed (15). THV sizing guidance is available from the mitral VIV app. Given the large pressure differential between the left ventricle and left atrium, the THV should be slightly larger than the surgical valve internal dimension, aiming for a 'conical' deployment with the ventricular aspect of the THV flared to prevent atrial migration.

\section{Tricuspid and pulmonary VIV}

Tricuspid and pulmonary VIV procedures have been associated with excellent outcomes (12). Femoral and jugular venous access are feasible with balloon-expandable THVs (Medtronic Melody and Edwards Sapien). Patients with prior TV repair with an incomplete annuloplasty ring have higher rates of paravalvular leak, which may require device-based closure (16).

\section{VIV thrombosis}

There is an increasing recognition of leaflet thrombosis, particularly in the setting of VIV implantation, which 
may lead to premature structural valve deterioration or stroke $(17,18)$. Leaflet thrombosis is often subclinical, with elevated transaortic gradients detected by echocardiography. Transesophageal echocardiography may be helpful, but '4D' volume-rendered CT is the gold standard for diagnosis. Anticoagulated patients appear less likely to develop leaflet thrombosis, leading some to recommend a period of anticoagulation after VIV procedures.

\section{Long term outcomes}

Excellent clinical outcomes have been reported at 1 year, with improvements in transaortic gradient and clinical benefit maintained (Table 1). However, these procedures are relatively new and the high-risk patients undergoing the procedure have had a relatively short life expectancy (19). Although THV durability appears favourable in the setting of native aortic valve stenosis, there are concerns about reduced durability in underexpanded VIV implants. Currently we know little about late durability of VIV implants.

\section{Summary}

Transcatheter VIV procedures have proven relatively safe and effective. Morbidity and mortality risks are generally lower than with surgery, and improvement in quality of life can be profound. Outcomes continue to improve with advances in THV technology, techniques, and expertise. However specific concerns remain; including residual stenosis, coronary obstruction, left ventricular outflow tract obstruction, and thrombosis. The unknown durability is a concern in patients with the potential for longevity. Still, it seems likely that transcatheter VIV procedures will increasingly be favoured over reoperation when bioprosthetic heart valves fail, particularly when surgical risks are high.

\section{Acknowledgements}

None.

\section{Footnote}

Conflicts of Interest: JG Webb: Consultant- Edwards Lifesciences. Another author has no conflicts of interest to declare.

\section{References}

1. Paradis JM, Del Trigo M, Puri R, et al. Transcatheter valve-in-valve and valve-in-ring for treating aortic and mitral surgical prosthetic dysfunction. J Am Coll Cardiol 2015;66:2019-37.

2. Thourani VH, Suri RM, Gunter RL, et al. Contemporary real-world outcomes of surgical aortic valve replacement in 141,905 low-risk, intermediate-risk, and high-risk patients. Ann Thorac Surg 2015;99:55-61.

3. Webb JG. Transcatheter valve in valve implants for failed prosthetic valves. Catheter Cardiovasc Interv 2007;70:765-6.

4. Wenaweser P, Buellesfeld L, Gerckens U, et al. Percutaneous aortic valve replacement for severe aortic regurgitation in degenerated bioprosthesis: the first valve in valve procedure using the Corevalve Revalving system. Catheter Cardiovasc Interv 2007;70:760-4.

5. Christakis GT, Buth KJ, Goldman BS, et al. Inaccurate and misleading valve sizing: a proposed standard for valve size nomenclature. Ann Thorac Surg 1998;66:1198-203.

6. Bapat V. Valve-in-valve apps: why and how they were developed and how to use them. EuroIntervention 2014;10 Suppl U:U44-51.

7. Chhatriwalla AK, Allen KB, Saxon JT, et al. Bioprosthetic valve fracture improves the hemodynamic results of valvein-valve transcatheter aortic valve replacement. Circ Cardiovasc Interv 2017;10:e005216

8. Webb JG, Mack MJ, White JM, et al. Transcatheter aortic valve implantation within degenerated aortic surgical bioprostheses: PARTNER 2 valve-in-valve registry. J Am Coll Cardiol 2017;69:2253-62.

9. Deeb GM, Chetcuti SJ, Reardon MJ, et al. 1-year results in patients undergoing transcatheter aortic valve replacement with failed surgical bioprostheses. JACC Cardiovasc Interv 2017;10:1034-44.

10. Yoon SH, Whisenant BK, Bleiziffer S, et al. Transcatheter mitral valve replacement for degenerated bioprosthetic valves and failed annuloplasty rings. J Am Coll Cardiol 2017;70:1121-31.

11. Bleiziffer S, Erlebach M, Simonato M, et al. Incidence, predictors and clinical outcomes of residual stenosis after aortic valve-in-valve. Heart 2018:104:828-34.

12. McElhinney DB, Cabalka AK, Aboulhosn JA, et al. Transcatheter tricuspid valve-in-valve implantation for the treatment of dysfunctional surgical bioprosthetic valves: an international, multicenter registry study. Circulation 2016;133:1582-93.

13. Allen KB, Chhatriwalla AK, Cohen DJ, et al. Bioprosthetic valve fracture to facilitate transcatheter valve-in-valve implantation. Ann Thorac Surg 2017;104:1501-8. 
14. Eleid MF, Cabalka AK, Williams MR, et al. Percutaneous transvenous transseptal transcatheter valve implantation in failed bioprosthetic mitral valves, ring annuloplasty, and severe mitral annular calcification. JACC Cardiovasc Interv 2016;9:1161-74.

15. Urena M, Himbert D, Brochet E, et al. Transseptal transcatheter mitral valve replacement using balloonexpandable transcatheter heart valves: a step-by-step approach. JACC Cardiovasc Interv 2017;10:1905-19.

16. Krishnaswamy A, Navia J, Kapadia SR. Transcatheter tricuspid valve replacement. Interv Cardiol Clin 2018;7:65-70.

Cite this article as: Murdoch DJ, Webb JG. Transcatheter valve-in-valve implantation for degenerated surgical bioprostheses. J Thorac Dis 2018;10(Suppl 30):S3573-S3577. doi: $10.21037 /$ jtd. 2018.05 .66
17. Makkar RR, Fontana G, Jilaihawi H, et al. Possible subclinical leaflet thrombosis in bioprosthetic aortic valves. N Engl J Med 2015;373:2015-24.

18. Chakravarty T, Sondergaard L, Friedman J, et al. Subclinical leaflet thrombosis in surgical and transcatheter bioprosthetic aortic valves: an observational study. Lancet 2017;389:2383-92.

19. Ye J, Cheung A, Yamashita M, et al. Transcatheter aortic and mitral valve-in-valve implantation for failed surgical bioprosthetic valves: an 8-year single-center experience. JACC Cardiovasc Interv 2015;8:1735-44. 